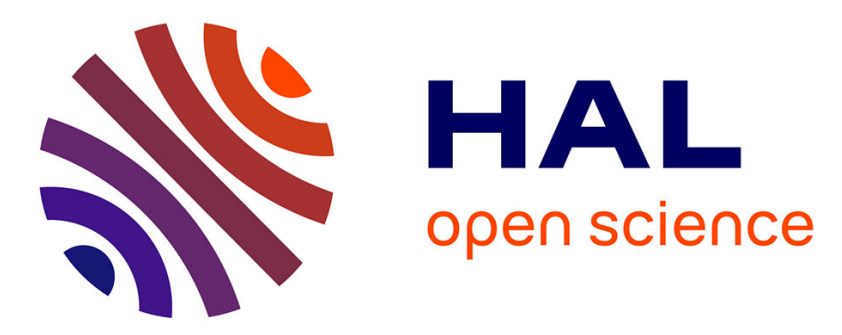

\title{
Adaptation of wheat and protein-mineral concentrate intakes by individual hens fed ad libitum in sequential or in loose-mix systems
}

\author{
Umar Faruk Murtala, Isabelle Bouvarel, Nathalie Même, Roffidal Lucien, \\ Tukur Hussaini, Yves Nys, Philippe Lescoat
}

\section{To cite this version:}

Umar Faruk Murtala, Isabelle Bouvarel, Nathalie Même, Roffidal Lucien, Tukur Hussaini, et al.. Adaptation of wheat and protein-mineral concentrate intakes by individual hens fed ad libitum in sequential or in loose-mix systems. British Poultry Science, 2010, 51 (06), pp.811-820. 10.1080/00071668.2010.532772 . hal-00652139

\section{HAL Id: hal-00652139 \\ https://hal.science/hal-00652139}

Submitted on 15 Dec 2011

HAL is a multi-disciplinary open access archive for the deposit and dissemination of scientific research documents, whether they are published or not. The documents may come from teaching and research institutions in France or abroad, or from public or private research centers.
L'archive ouverte pluridisciplinaire HAL, est destinée au dépôt et à la diffusion de documents scientifiques de niveau recherche, publiés ou non, émanant des établissements d'enseignement et de recherche français ou étrangers, des laboratoires publics ou privés. 


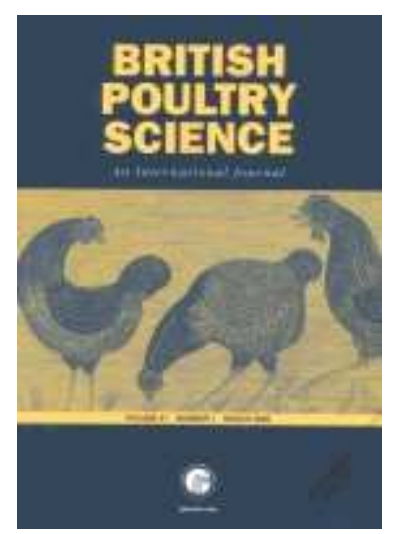

\section{Adaptation of wheat and protein-mineral concentrate intakes by individual hens fed ad libitum in sequential or in loose-mix systems}

\begin{tabular}{|c|c|}
\hline Journal: & British Poultry Science \\
\hline Manuscript ID: & CBPS-2009-365.R4 \\
\hline Manuscript Type: & Original Manuscript \\
\hline $\begin{array}{l}\text { Date Submitted by the } \\
\text { Author: }\end{array}$ & 02-Jun-2010 \\
\hline Complete List of Authors: & $\begin{array}{l}\text { Murtala, UMAR FARUK; INRA, Tours, UR83 recherches avicoles } \\
\text { Bouvarel, Isabelle; ITAVI } \\
\text { Nathalie, MEME; INRA Tours, UR83 recherches avicoles } \\
\text { Lucien, ROFFIDAL; INZO } \\
\text { Hussaini, Tukur; Usman Danfodio University, Department of Animal } \\
\text { Science } \\
\text { Nys, Yves; INRA Tours, UR83 recherches avicoles } \\
\text { Lescoat, Philippe; INRA Tours, UR83 recherches avicoles }\end{array}$ \\
\hline Keywords: & $\begin{array}{l}\text { sequential feeding, loose-mix feeding, Feed intake, whole-wheat, } \\
\text { Laying hen }\end{array}$ \\
\hline
\end{tabular}

\section{SCHOLARONE" Manuscripts}


1 2 3 4 5 6 7

Running title: Feeding system and performance in hens

Correspondence to: Dr. P. Lescoat, INRA, UR83 Recherches Avicoles, F-37380 Nouzilly, France.

E-mail: lescoat@tours.inra.fr

\section{Accepted for publication 8th June 2010}


41 Abstract 1. Feed intake and performance of birds given sequential or loose-mix feeding was 42 investigated from 19 to 42 weeks of age. A complete diet was fed as control (C). A balancer 43 diet (50) was fed either sequentially (S50) or in a loose-mix (L50) with wheat. This diet was 44 formulated to provide a similar nutritive value as $\mathrm{C}$ assuming a 50:50 diet and wheat intake. 45 Another balancer diet (25) was fed sequentially (S25) or in a loose-mix (L25) with wheat. The 46 diet was to provide a similar nutritive value as $C$ assuming 75:25 diet and wheat intakes. In 47 sequential feeding, only wheat was fed in the morning (4h after lights-on) and the balancer 48 diet in the late afternoon ( $4 \mathrm{~h}$ before lights-off). In the loose-mix treatment, a mixture of the 49 two diets was fed throughout the 16-h daily light. Each treatment was given ad libitum to 25 50 birds in individual cages.

51 2. Birds fed on L25 had lower total feed intakes than those receiving C, S50 or S25. Protein 52 intake was reduced with L25 compared to C, S50, S25 and L50. ME intake was, however, 53 similar among all treatments. Egg production and weight were reduced with L25 compared to 54 S50 and S25. BW was lowered with L25. However, there was high individual variation in all 55 variables.

56 3. Feeding system (sequential vs loose-mix) had no effect on ME intake. However the loose57 mix treatment reduced feed and protein intake due to lower balancer diet intake. It also 58 resulted in low egg production, egg and body weights compared to sequential feeding. The 59 weights of pancreas and gizzard were heavier with sequential and loose-mix compared to the 60 control.

61 4. The loose-mix treatment reduced egg-laying performance. Sequential feeding resulted in 62 similar egg-laying performance to conventional feeding and thus could be used to advantage 63 in situations where it is applicable. 
64

65

66

\section{INTRODUCTION}

The use of whole cereal grain in poultry feeding is a popular practice in Northern Europe. The reason has been the economic benefit as well as the local availability of these feedstuffs. In countries where the cost of feed mixing hinders production, direct incorporation of cereal grains could be an alternative. Although the benefits depend on the relative price of cereals, it is important to have a clear knowledge of the impact of incorporating cereal grains in poultry feeds on bird performance. Different methods such as choice feeding, loose-mix feeding and sequential feeding can be used to offer cereal grains to poultry (Noirot et al., 1998). Choice feeding is the simultaneous feeding of grains and a protein-mineral concentrate placed in different containers. Loose-mix feeding is the distribution of these dietary components in a single container. Sequential feeding involves the distribution of the two dietary components separately at different times of the day. Choice feeding using cereal grains is accompanied by an improvement in feed utilisation because it allows a degree of feed selection by the animal (Forbes and Covasa, 1995; Noirot et al., 1998). It has, however, the inconvenience of requiring more than one feed trough to offer the different diets. Loose-mix and sequential feeding, however, could be practical alternatives since only one trough is required.

Studies evaluating sequential and loose-mix feeding in laying hen are limited. Loosemix feeding of laying hens was reported to reduce both feed and protein intakes when a mixture of whole wheat, whole barley, kibbled maize and pellet protein concentrate was offered (Blair et al., 1973), or when fed on a (50:50) mixture of high energy/protein Ca diets (Lee and Ohh, 2002). Although the former observed similar egg production and egg weight to conventional feeding, the latter reported a decrease in egg weight, which was related to a decrease in energy intake. Loose-mix feeding of $60 \%$ barley and a protein concentrate was reported to increase feed, energy and protein intakes, but to reduce egg production while increasing egg weight (Bennet and Classen, 2003). However, when the quantity of whole 
89 wheat in a loose-mix diet was limited to $20 \%$, similar intakes and egg production were 90 observed (Kermanshashi and Classen, 2001; MacIsaac and Anderson, 2007).

Sequential feeding of a mixture of whole cereals followed by a pelleted protein 92 concentrate resulted in increased feed and protein intakes while maintaining similar energy 93 intake, egg production and egg weight compared to a control diet (Blair et al., 1973). 94 Nevertheless, sequential feeding was reported to reduce feed, energy and protein intakes when 95 birds were fed on a protein concentrate in the morning followed by whole oats in the 96 afternoon (Robinson, 1985), or when fed on high-energy diet in the morning and protein 97 concentrate in the afternoon (Leeson and Summers, 1978; Reichmann and Connor, 1979; Lee 98 and Ohh, 2002). Except for the work of Blair et al. (1973), all the other studies have reported 99 that sequential feeding results in lower egg production and egg weights.

100 Recent investigations on the sequential and loose-mix feeding of whole wheat and a 101 protein-mineral concentrate in laying hen revealed that sequential feeding was more efficient 102 compared to loose-mix and the conventional feeding of a complete diet (Umar Faruk et al., 103 2010). However, it was possible that this increased efficiency was linked to the experimental 104 protocol used. Feed intake was controlled by feeding a limited quantity $(121 \mathrm{~g} / \mathrm{bird} / \mathrm{d})$ of a 105 diet that contained $60.5 \mathrm{~g}$ each of whole wheat and concentrate. Birds were kept in groups and 106 this can facilitate social interactions among individuals and modify the birds' feeding patterns 107 through imitation (Meunier-Salaün and Faure, 1984). This management system also prevents 108 the study of individual responses to sequential and loose-mix feeding, since only the average 109 cage values could be measured.

110 The objective of the present experiment was to investigate the impact of sequential and 111 loose-mix feeding of birds kept in individual cages and given the diets ad libitum. 112 Furthermore, the study investigated the ability of birds under these feeding systems to adapt 113 their feed intake according to their requirements. 


\section{MATERIALS AND METHODS}

\section{Pre-experimental period (weeks 16 - 18)}

116 A total of 149 ISA Brown layer hens were trained (Forbes and Covasa, 1995) from week 16

117 to 18 to get them habituated to the feeding systems studied. The specific objective was to 118 adapt the sequentially-fed birds to whole-wheat intakes before they reached point of lay 119 (Umar Faruk et al., 2008). The animals were housed in a three-tier battery having individual 120 cages $(25 \times 38 \mathrm{~cm})$. Each cage was equipped with a feed trough $(20 \mathrm{~cm}$ per hen) and a nipple 121 drinker. A complete diet, named 'control habituation' (Table 1) and containing $160 \mathrm{~g} \mathrm{CP} / \mathrm{kg}$ 122 and $11.7 \mathrm{MJ} / \mathrm{kg}$, was fed to a group of 33 birds as control $(\mathrm{CH})$. Another diet, named 'balancer 123 diet habituation' and containing $180 \mathrm{~g} \mathrm{CP} / \mathrm{kg}$ and $11.0 \mathrm{MJ} / \mathrm{kg}$, was fed sequentially (SH) with 124 wheat $(13.0 \mathrm{MJ} / \mathrm{kg})$ to another group containing 58 birds. Hens in this group were given 125 access to whole wheat (Triticum aestivum) in the morning and to the balancer diet in the 126 afternoon. The same diet, 'balancer diet habituation', was mixed with whole wheat and fed in a 127 loose-mix (LH) to another group containing 58 birds. The 'balancer diet habituation' was 128 formulated on the assumption that if the birds consumed $65 \%$ of it and $35 \%$ whole wheat, 129 they would ingest an equal amount of nutrients as those receiving diet $\mathrm{CH}$.

Table 1 near here

130 Birds were fed ad libitum in line with the breeders' guidelines (ISA Hendrix Genetics,

131 2007). The total quantity of diet offered was progressively increased to account for the

132 increase in feed intake of a growing bird; it was increased from $70 \mathrm{~g} / \mathrm{bird} / \mathrm{d}$ in week 16 to 83

$133 \mathrm{~g} / \mathrm{bird} / \mathrm{d}$ in week 18. In sequential feeding, the duration for which birds were given access to 134 wheat was increased in equal amounts from $3 \mathrm{~h} / \mathrm{d}$ (week 16) to $7 \mathrm{~h} / \mathrm{d}$ (week 18). The 135 photoperiod was $10 \mathrm{~h}$ at week 16 and reached $16 \mathrm{~h}$ at week 18 . Water was given ad libitum 136 throughout the study.

\section{Experimental period (weeks 19 - 42)}


138 Five treatments were introduced at 19 weeks of age. Each of the sequential and loose-mix

139 groups was divided into two groups to form 4 treatments of 25 birds each. The other 25 birds

140 from the $\mathrm{CH}$ group formed the control treatment. During the experimental period, the birds

141 were housed in the same house and kept in the individual cages that were used during the

142 habituation period. Body weight (BW) was used as criterion for the placement of the birds so

143 as to obtain a similar intra treatment BW. However, due to limited number of birds habituated

144 and the random choice of birds dissected for the measurement of the digestive organs, initial

$145 \mathrm{BW}$ for the treatment L50 was lower than C, S50 or S25. Photoperiod was $16 \mathrm{~h}$ and

146 temperature was maintained at $20.6 \pm 1.8^{\circ} \mathrm{C}$ throughout the experimental period.

147 A complete diet (Table1) containing $175 \mathrm{~g} \mathrm{CP} / \mathrm{kg}$ and $11.5 \mathrm{MJ} / \mathrm{kg}$ was fed ad libitum

148 as the control treatment (C). To investigate the ability of laying hens to adapt their intake

149 according to their energy and protein requirements, the balancer diet B50 (232 g CP / $\mathrm{kg}, 10.0$

$150 \mathrm{MJ} / \mathrm{kg}$ ) was formulated to provide a similar nutritive value to $\mathrm{C}$ and assuming that the birds

151 would ingest equal quantities (50:50) of the diet and whole wheat. This diet was fed to two

152 experimental groups either sequentially (S50) or as a loose-mix (L50). Another balancer diet

$153 \mathrm{~B} 25(195 \mathrm{~g} \mathrm{CP} / \mathrm{kg}, 11.0 \mathrm{MJ} / \mathrm{kg})$ was formulated to provide similar nutritive values as $\mathrm{C}$ and

154 assuming that the birds would ingest it on a 75:25 basis with wheat. It was fed to the other

155 two groups either sequentially (S25) or in loose-mix (L25). Diets were fed ad libitum

156 containing equal amount of each of the fractions (wheat/protein mineral concentrate). Birds

157 fed on the B50 diet were expected to have a 50\% wheat intake, while only $25 \%$ wheat intake

158 was expected for those fed on the B25 diet. Calcium carbonate (Ca) was ground and

159 incorporated in the balancer diet since the separate provision of granular $\mathrm{Ca}$ is not a

160 prerequisite when birds are fed on nutrient-fractioned diets (Balnave and Muritasari, 1990).

\section{Measurements}


162 Feed intake was measured weekly. In the two $\mathrm{S}$ fed treatments, wheat and balancer diet

163 intakes were determined separately. During the experimental period, wheat intake in L was 164 measured after manual separation using a sieve $(2 \mathrm{~mm} \Phi)$.

Eggs were collected daily and weighed individually. The weight of egg components

166 (yolk, albumen and shell) was determined on a daily sample every 4 weeks, starting at week

167 21. The albumen and the chalazae were separated using forceps prior to weighing the yolk.

168 The shells were washed and dried for $12 \mathrm{~h}$ in a drying oven at $70^{\circ} \mathrm{C}$ and then weighed.

169 Birds were weighed individually at 16, 19, 26 and 37 weeks of age. The weight of the

170 digestive organs was recorded at the end of the pre-experimental (week 19) and experimental

171 (week 42) periods to assess the effect of the feeding system on these organs. The birds were 172 weighed before being injected with sodium pentobarbital solution ( $1 \mathrm{ml} / \mathrm{kg}$ body weight). The 173 abdominal cavity was opened and the digestive tract dissected and separated into 174 proventriculus, gizzard, duodenum, pancreas, jejunum and ileum. The segments were first 175 emptied and dried using a paper towel before weighing. The proventriculus and the gizzard 176 were placed in an ice container $\left(-4^{\circ} \mathrm{C}\right)$ for $3 \mathrm{~h}$ to facilitate the removal of the surrounding fat. 177 The organs were emptied prior to weighing.

178 Metabolisable energy $(\mathrm{kJ} / \mathrm{b} / \mathrm{d})$ and protein $(\mathrm{g} / \mathrm{b} / \mathrm{d})$ intakes were estimated as a product 179 of feed intake and $\mathrm{ME}$ and protein contents of the experimental diets respectively. ME 180 requirement was estimated according to Sakomura (2004)

$$
M E(\mathrm{~kJ} / \mathrm{b} / \mathrm{d})=W^{0.75 *}(165.74-2.37 * T)+6.68 * W G+2.40 * E M
$$

182 where, $M E=$ energy requirement $(\mathrm{kJ} / \mathrm{bird} / \mathrm{d}), W=$ Body weight $(\mathrm{kg}), T=$ Temperature $\left({ }^{\circ} \mathrm{C}\right)$, $183 W G=$ weight gain $(\mathrm{g} / \mathrm{d}), E M=$ Egg mass $(\mathrm{g} / \mathrm{bird} / \mathrm{d})$.

184 Protein requirement was estimated according to Sakomura et al., (2002)

$$
P B=1.94 * W^{.075}+0.480 * G+0.301 * E M
$$


186 where, $P B=$ protein requirement $(\mathrm{g} / \mathrm{bird} / \mathrm{d}), \mathrm{W}=$ body weight $(\mathrm{kg}), G=$ daily weight gain

$187(\mathrm{~g} / \mathrm{d})$ and $E M=$ egg mass $(\mathrm{g} / \mathrm{bird} / \mathrm{d})$.

188 Statistical analysis

189 Individual values from cages were analysed using StatView (version 5, SAS Institute Inc.,

190 Cary, NC). A one-way ANOVA was performed using the GLM model to test the treatment

191 effect on feed intake, egg production, egg weight, body weight, digestive organs weight, ME

192 intake and requirements. A 2x2 factorial ANOVA was carried out to test the effect of feeding

193 system (loose-mix vs sequential) and balancer diet effect (50 vs 25). Results were considered

194 significantly different if $P<0.05$ and Bonferroni-Dunnet pairwise comparison was used to

195 compare differences between means. Repeated measures ANOVA was performed on BW,

196 feed and wheat intakes, and egg mass to test the effect of treatment over time.

197

\section{RESULTS}

198 During the habituation period, no differences in total feed intakes were observed between the 199 treatments $(62.4,62.5$ and $62.4 \pm 0.3 \mathrm{~g} / \mathrm{bird} / \mathrm{d}$ for $\mathrm{CH}, \mathrm{LH}$ and $\mathrm{SH}$ respectively). The wheat 200 intakes of the birds given the SH treatment increased from 13.0 to $40.0 \mathrm{~g} / \mathrm{bird} / \mathrm{d}$ from week 16 201 to 18 respectively. Their balancer-diet intake, however, decreased with increasing age and 202 wheat intake from $51.6 \mathrm{~g} / \mathrm{bird} / \mathrm{d}$ in week 16 to $40.0 \mathrm{~g} / \mathrm{bird} / \mathrm{d}$ in week 18 . This increase in 203 wheat intake with the resulting decrease in balancer diet intake during this period suggested a 204 successful adaptation to wheat intake for SH-fed birds. There were no differences in BWG 205 between week 16 and week 18 (8.1, 8.3, and $8.6 \pm 0.1 \mathrm{~g} / \mathrm{bird} / \mathrm{d}$ for $\mathrm{CH}$, LH and SH 206 respectively).

207 During the experimental period, the mean total feed intake was lower for birds given 208 the treatment L25 than C, S50 and S25, although it was similar to L50 (Table 2). Figure (b) 209 shows the weekly change in feed intake according to treatment from 19 to 42 weeks. There 210 was a significant increase in feed intake in all treatments with time, although birds fed on L25 
211 and L50 had lower feed intakes from week 30 of age but with a higher weekly variability than 212 the other three treatments. Wheat intake was higher for birds given L50, L25, S50 and S25 213 (Table 2). There was a progressive but significant decrease in wheat intake over time, 214 especially with treatments S25 and S50 (Figure c).

215 Egg production and egg weight were reduced with L25 compared with S50 and S25

216 (Table 2). Egg production and weight were, however, not statistically different between L25,

217 L50 and C. Birds in treatment L25 had a significantly smaller egg mass and lower egg yolk 218 weight compared with the other 4 treatments. Egg mass in this treatment was progressively 219 reduced from week 23 and was generally low through out the experimental period (Figure d). 220 Eggshell weight was significantly reduced with L25 when compared with S25, S50 and L50. 221 There were no significant treatment differences for albumen weight. Feed conversion ratios 222 (FCR) were similar among all treatments. Table 2 and Figure near here BW at week 19 was significantly lower for birds receiving L50 than for C, S50 and 224 S25, although they were similar to L25 (Table 2); this was associated with the low BW of the 225 treatment group upon arrival at week 16 (Figure a). Although L50 was initially low in BW, 226 the final BW (week 42) was lower for L25 compared with C, S25 and S50. The Figure (a) 227 shows that the birds which received L50 had a similar growth rate to the other treatments. 228 Conversely, L25, which was similar in BW to all treatments at the beginning of the 229 experiment, had reduced growth, thus having a lower BW than C, S50 and S25 at the end of 230 the experiment.

231 Feeding system affected the birds' feed intakes and egg-laying performance and the 232 birds fed sequentially had higher total feed intakes than those fed on the loose-mix (Table 2). 233 The latter had higher wheat intakes. Hens fed sequentially had higher egg numbers, egg 234 weight and albumen weight than those fed on the loose-mix. BW was higher in the birds fed 
235 sequentially than with those fed on loose-mix and this was associated with the higher initial 236 BW. FCR and BWG were similar for the two systems.

237 Birds receiving balancer diet optimised for $25 \%$ wheat intake had lower mean total 238 feed and wheat intakes compared with those receiving diet optimised for 50\% (Table 2). Egg 239 numbers, egg weight, egg albumen weight, FCR and final BW were similar for these two 240 diets. However, BWG was higher in the birds fed on balancer diet optimised for 50\% wheat 241 intake compared with that optimised for $25 \%$.

242 There was a similar ME intake for all treatment groups (Table 3). Estimated ME 243 requirement for treatment L25 was lower than that of C, S50 and S25 but similar to L50. The 244 difference between ME intake and ME requirement was higher for birds fed on L25 than S50, 245 S25 or C, although it was similar to L50, indicating a surplus in ME intake of birds in these 246 treatment groups. Protein intake was reduced with L25-fed birds compared with the other 4 247 treatments. Protein intake of birds fed on L50 was lower than C and S50 but similar to S25. 248 The estimated protein requirement was reduced in birds fed on L25 compared with C, S50 249 and S25 but similar to L50. The difference between protein intake and requirement was small 250 for birds fed on L25 and S25 compared with those fed on S50. Table 3 near here 251 ME intake was similar for the sequential and loose-mix systems (Table 3). Estimated 252 ME requirement of sequentially fed birds was significantly higher than the loose-mix group. 253 The difference between ME intake and estimated requirement was lower for birds fed 254 sequentially. Both intake and estimated requirement of protein were significantly higher in 255 birds fed sequentially than in those fed on loose-mix.

256 ME intake and estimated requirements and the differences between ME intake and 257 estimated requirement were similar between the two balancer diets (Table 3). Protein intake 258 was low for birds receiving the balancer diet formulated for $25 \%$ wheat intake relative to 
259 those receiving the diet with balancer formulated for 50\%. Protein requirement was similar 260 for the two diets.

At the end of habituation period (week 19), similar relative weights of proventriculus,

262 liver and pancreas were observed between $\mathrm{CH}, \mathrm{SH}$ and $\mathrm{LH}$ (Table 4). The relative weight of 263 the duodenum was lower for birds in the LH group than SH. The relative weight of the ileum 264 was heavier for birds in $\mathrm{SH}$ group than with those in $\mathrm{LH}$ and $\mathrm{CH}$. There were significant 265 differences in gizzard and jejunum weights between the treatment groups, but the differences 266 were not proven using the Bonferroni-Dunnet pairwise comparison test due, probably because 267 of the limited number of birds killed (8/treatment). Table 4 near here 268 At the end of the experimental period (week 42), the proventriculus was heavier in the 269 birds given $\mathrm{S}$ than the $\mathrm{C}$ and $\mathrm{L}$ treatments; the gizzard was heavier for the $\mathrm{S}$ and $\mathrm{L}$ treatments 270 compared with $\mathrm{C}$; the duodenum was heavier for S compared with $\mathrm{C}$; the liver was heavier 271 with the $\mathrm{L}$ treatment compared with $\mathrm{C}$ and the pancreas was heavier for $\mathrm{S}$ and $\mathrm{L}$ treatments 272 compared with C. There were no significant differences in the weights of the jejunum and 273 ileum between the three treatments.

275 None of the 4 treatments receiving whole wheat had a daily wheat intake that met the 276 expected 25 or $50 \%$ of the total daily feed intake. The birds receiving the diet formulated for $27750 \%$ wheat intake consumed slightly less wheat (47\%) than anticipated, whereas those fed on 278 the diet formulated for $25 \%$ wheat intake consumed more wheat $(41 \%)$. However, no 279 treatment differences in ME intake were observed, which suggests that there was an 280 adjustment by the sequential and loose-mix fed birds to consume a similar ME to those fed on 281 the complete diet C. This lends support to work of Blair et al. (1973), Kermanshashi and 282 Classen (2001) and MacIsaac and Anderson (2007), who reported similar ME intakes in birds 283 fed on a loose-mix or complete diet. However, in sequential feeding, Leeson and Summers 
284 (1978), Reichmann and Connor (1979), Robinson (1985), and Lee and Ohh (2002) reported a 285 decrease in ME intake, along with a reduced feed intake, which was not the case in the present 286 work.

Birds fed sequentially had higher feed intakes compared with the loose-mix treatment, 288 but this was not in accordance to our earlier work with birds housed in groups (Umar Faruk et 289 al., 2010), where a higher feed intake was obtained with loose-mix than with sequential 290 feeding. In this earlier work, the birds were housed in groups and fed on limited quantities of 291 the two dietary fractions. The lower feed intakes with loose-mix in the present experiment 292 was mainly attributed to treatment L25, because of its similar balancer diet intake compared 293 to L50. Although L25 fed birds consumed more wheat than expected, their balancer diet 294 intake remained similar to L50, thereby reducing their total intake.

295 The higher wheat intake when birds were fed with a loose-mix relative to those fed 296 sequentially agree with earlier observations under different conditions (Umar Faruk et al., 297 2010). Increased wheat intake has been associated with larger feed particle preference in 298 laying hens (Picard et al., 1997; Umar Faruk et al., 2008). Portella et al. (1988) observed a 299 greater disappearance of larger particles when birds were fed on regular crumbles, and the 300 smaller particles disappeared only as the concentration of large ones decreased. In the present 301 work, the inclusion of whole wheat in the concentrate diet is likely to have increased the 302 heterogeneity of the diet, thus increasing selection of the larger particles (whole wheat) first. 303 Birds fed sequentially consumed more balancer diet than those fed on a loose-mix. 304 Blair et al. (1973) observed an increased feed intake when birds were fed sequentially and, in 305 particular, when there was a high intake of protein concentrate. However, sequential feeding 306 using an energy-rich diet in the morning and a protein concentrate in the afternoon (Leeson 307 and Summers, 1978; Reichmann and Connor, 1979) reduced feed intake. Feed intake was also 308 reduced when oats/sorghum were sequentially fed with a protein concentrate (Robinson, 
309 1985). Lee and Ohh (2002) also reported a reduction in feed intake when birds were fed on a 310 high energy/protein and low $\mathrm{Ca}$ diet in the morning followed by a low energy/protein and 311 high $\mathrm{Ca}$ in the afternoon. In the present work, the high balancer diet intake with the sequential 312 feeding agreed with the feeding patterns observed with laying hens (Ballard and Biellier, 313 1969; Nys et al., 1976; Keshavarz, 1998a,b; Choi et al., 2004). Birds consume larger amount 314 of food in the afternoon partly in association with the hen $\mathrm{Ca}$ appetite which coincides with 315 the initiation of eggshell formation during this period. For example, Keshavarz (1998a) found 316 that hens subjected to a 16-h photoperiod consumed $40 \%$ of daily feed intake in the first $8 \mathrm{~h}$ 317 after light-on and $60 \%$ during the second $8 \mathrm{~h}$ period before light-off, with a marked increase 318 recorded $4 \mathrm{~h}$ before light-off (Keshavarz, 1998b).

319 The laying hen adapts its feed intake relatively well to the energy value of its feed, 320 although this regulation is not perfect (Joly and Bougon, 1997), because the hen is influenced 321 by the form and method in which the feed is presented. Data in the present work were 322 subjected to a $t$-test to see if the ME intake minus ME requirement were different from zero. 323 Results showed that no difference between the ME intake and the ME requirements for the 324 birds in groups $\mathrm{C}$ as well as L50, suggesting that the two groups have adapted their ME intake 325 to their estimated requirements. However, birds fed on S50 and S25 had lower ME intakes 326 than the estimated requirements. L25 had a significantly higher intake than requirement, 327 although their efficiency of utilising this energy was apparently poor because they had the 328 lowest performance. Despite their lower-than-estimated ME intake, the birds fed on S50 and 329 S25 had similar egg-laying performance to those fed on the control diet. This was also 330 observed in previous work (Umar Faruk et al., 2010) and in the earlier work of Leeson and 331 Summers (1978) and Reichmann and Connor (1979), who observed that sequential feeding 332 reduced the mean feed intake without reducing egg production, relative to the control. These 333 authors associated it to lower maintenance requirements due to the lower body weights in the 
334 sequentially fed birds. In the present work, it may be due to an improvement in the rate of

335 utilisation of nutrients evidenced by a heavier gizzard, proventriculus and duodenum observed 336 with sequential than the loose-mix or control birds.

337 Loose-mix-fed birds laid fewer eggs and had a lower egg weight than those fed 338 sequentially. A reduction in protein intake is usually accompanied by a reduction in both egg 339 production and egg weight (Morris and Gous, 1988), and protein intakes were lower with 340 loose-mix treatment. Ad libitum access to the diets gave higher wheat consumption in the 341 loose-mix birds (Umar Faruk et al., 2008), which resulted in a low overall protein intake.

342 At the end of the experimental period, the sequential and loose-mix fed birds had 343 heavier gizzards than those receiving the control diet. This was to be expected because 344 feeding whole wheat grain increases the dietary particle size of the diets, and dietary particle 345 size is known to influence the avian digestive tract (Nir et al., 1990). This increase in gizzard 346 weight was hypothesised to contribute to the better performance of sequentially-fed, group347 housed hens studied by Umar Faruk et al. (2010). In the present work, no improvement in 348 performance was observed; this was likely to be a consequence of the broad intra-treatment 349 variations and the ad libitum feeding. Changes in liver weight were in line with the findings of 350 De Basilio et al. (2001), who found heavier livers in broilers that had been fed on cereal 351 grains. It was also in line with the observations of Umar Faruk et al. (2010), who observed 352 heavier liver weights in birds fed on whole wheat.

353 In conclusion, the present study confirmed our earlier report (Umar Faruk et al., 2010)

354 that sequential feeding has no adverse effect on egg production, thus outlining its potential as 355 a feed management method for egg producers. When birds are allowed ad libitum access to 356 concentrate diets formulated for different proportion of wheat intake, it is evident that they 357 will not always consume the expected proportion of the respective fractions. In sequential 358 feeding, similar feed intakes and egg-laying performance to the control group were obtained 
359 irrespective of the concentrate diet used. This system could therefore be used to advantage in 360 situations where the cost of grinding and feed mixing hinders production. In loose-mix 361 feeding, distributing concentrated diets optimised for $25 \%$ wheat intake reduced nutrient 362 intake and performance as the hens failed to eat the appropriate proportion of the dietary 363 fractions, and so this management technique should be avoided.

364 The advantages of sequential feeding needs to be further explored in terms of the 365 physical form (whole, ground) and type of cereals (millet, sorghum, maize etc) to be used. Ad 366 libitum feeding in sequential feeding resulted in excessive intake of the concentrate diet and 367 this may increase cost and so requires additional investigation. Feeding management (van 368 Krimpen et al., 2005), especially sequential feeding (Jordan et al., 2009), induces feather 369 pecking in laying hens, due to a reduction in time spent on feeding activity. Therefore, the 370 optimal duration of the sequence (wheat-balancer diet) in sequential feeding needs to be 371 established.

\section{ACKNOWLEDGEMENTS}

373 The authors acknowledge the technical assistance given by Jean-Marc Hallouis, Anne-Marie 374 Chagneau, Maryse Leconte and Serge Mallet. They also thank Lucille Delestre, Valentine 375 Froget and Amandine Soria for their help in data collection. The help of our experimental unit 376 (UE PEAT) in the set-up of this experiment was highly appreciated. Finally we thank France 377 AgriMer, $\mathrm{CNPO}$ and $\mathrm{INZO}^{\circ}$ for their financial support.

\section{REFERENCES}

380 BALLARD, P.D. \& BIELLIER H.V. (1969) The effect of photoperiod and oviposition on 381 feed and water consumption by chickens. Poultry Science, 48: 1781-1782. 
382 BALNAVE, D. \& ABDOELLAH, T. M. (1990) Self-select feeding of commercial pullets 383 using a complete diet and a separate protein concentrate at cool and hot temperatures. 384 Australian Journal of Agricultural Research, 41: 549-555.

385 BENNET, C. D. \& CLASSEN, H.L. (2003) Performance of two strains of laying hens fed 386 ground and whole barley with and without access to insoluble grit. Poultry Science, 82: $387 \quad 147-149$.

388 BLAIR, R., DEWAR, W.A. \& DOWNIE, J.N. (1973) Egg production responses of hens 389 given a complete mash or unground grain together with concentrate pellets. British Poultry $390 \quad$ Science, 14: 373-377.

391 CHOI, J. H., NAMKUNG, H. \& PAIK, I.K. (2004) Feed consumption pattern of laying hens 392 in relation to time of oviposition. Asian-Australasian Journal of Animal Science, 17: 371$393 \quad 373$.

394 DE BASILIO, V., VILARIÑO, M., YAHAV, S. \& PICARD, M. (2001) Early age thermal 395 conditioning and a dual feeding program for male broilers challenged by heat stress. 396 Poultry Science, 80: 29-36.

397 FORBES, J.M. \& COVASA M. (1995) Application of diet selection by poultry with 398 particular reference to whole cereals. World's Poultry Science Journal, 51: 149-165.

399 ISA Hendrix Genetics Company (2007) Nutrition Management Guide, 18p.

400 JOLY, P. \& BOUGON, M. (1997) Influence du niveau énergétique sur les performances de la 401 pondeuse à œufs roux et évolution de l'ingérée en fonction de l'âge. 2ème Journées de la 402 recherches avicoles, 8-9-10 Avril 1997, 2: 115-120.

403 JORDAN, D., UMAR FARUK, M., CONSTANTIN, P., ALI, M. N., BESSEI, W., 404 LESCOAT, P., STUHEC, I., BOUVAREL, I. \& LETERRIER, C. (2009) The influence of 405 sequential feeding with wheat on laying hens' feeding and pecking behaviour. Abstracts 8th 406 European Symposium on Poultry Welfare, Cervia pp. 16. 
407 KERMANSHASHI, H. \& CLASSEN, H.L. (2001) Feeding whole wheat with or without a 408 dietary enzyme or grit to laying hens: Journal of Agricultural Science and Technology, 3: $409 \quad 193-198$.

410 KESHAVARZ, K. (1998a) Investigation on the possibility of reducing protein, phosphorus 411 and calcium requirements of laying hens by manipulation of time of access to these 412 nutrients. Poultry Science, 77: 1320-1332.

413 KESHAVARZ, K. (1998b) Further investigations on the effect of dietary manipulation of 414 protein, phosphorus, and calcium for reducing their daily requirement for laying hens. $415 \quad$ Poultry Science, 77: 1333-1346.

416 LEE, K. H. \& OHH, Y.S. (2002) Effects of nutrient levels and feeding regimen of a.m. and 417 p.m. on laying hen performances and feed cost. Korean Journal of Poultry Science, 29: $418 \quad 195-204$.

419 LEESON, S. \& SUMMERS, D.J. (1978) Voluntary food restriction by laying hens mediated 420 through dietary self selection. British Poultry Science, 19: 417-424.

421 MACISAAC, J.L. \& ANDERSON, D.M. (2007) Effect of whole wheat, enzyme 422 supplementation and grain texture on the production performance of laying hens. Canadian 423 Journal of Animal Science, 87: 579-589.

424 MEUNIER-SALAÜN, M. C. \& FAURE, J. M. (1984) On the feeding and social behaviour of 425 the laying hen. Applied Animal Behaviour Science, 13: 129-141.

426 MORRIS, T.R. \& GOUS, R.M. (1988) Partitioning of the response to protein between egg 427 numbers and egg weight. British Poultry Science, 29: 93-99

428 NIR, I., MELCION, J-P. \& PICARD, M. (1990) Effect of particle size of sorghum grains on 429 feed intake and performance of young broilers. Poultry Science, 69: 2177-2184

430 NOIROT, V., BOUVAREL, I., BARRIER-GUILLOT, B., CASTAING, J., ZWICK J. L. \& 431 PICARD, M. (1998) Céréales entières pour les poulets de chair: le retour? INRA 
Productions Animales, 11: 349-357.

433 NYS, Y., SAUVEUR, B., LACASSAGNE, L. \& MONGIN, P. (1976) Food, calcium and 434 water intakes by hens lit continuously from hatching. British Poultry Science, 17: 351-358. 435 PICARD, M., MELCION, J-P., BOUCHOT, C. \& FAURE, J-M. (1997) Picorage et 436 préhensibilité des particules alimentaires chez les volailles. INRA Productions Animales, 437 10: $403-414$.

438 PORTELLA, F.J., CASTON, L.J. \& LEESON, S. (1988) Apparent feed particle size 439 preference in laying hens. Canadian Journal of Animal Science, 68: 915-922.

440 REICHMANN, K.G. \& CONNOR, J.K. (1979) The effects of meal feeding of calcium, 441 protein and energy on production and calcium status of laying hens. British Poultry $442 \quad$ Science, 20: 445-452.

443 ROBINSON, D. (1985) Performance of laying hens as affected by split time and split time 444 composition dietary regimens using ground and unground cereals. British Poultry Science, $445 \quad$ 26: $299-399$.

446 SAKOMURA, N.K., (2004) Modelling energy utilization in broiler breeders, laying hens and 447 broilers. Brazilian Journal of Poultry Science, 6: 1-11.

448 SAKOMURA, N.K., BASAGLIA, R. \& TOMAS DE RESENDE, K. (2002) Modelling 449 protein utilization in laying hens. Revista Brasileira de Zootecnia, 31: 2247-2254.

450 UMAR FARUK, M., DEZAT, E. BOUVAREL, I. NYS, Y. \& LESCOAT P. (2008) Loose451 mix and sequential feeding of mash diets with whole-wheat: effect on feed intake in laying 452 hens. Proceedings of XXIIIrd Worlds' Poultry Congress, Brisbane, Australia, p. 468.

453 UMAR FARUK, M., BOUVAREL, I., MEME, N., RIDEAU, N., ROFFIDAL, L., TUKUR, 454 H.M., BASTIANELLI, D., NYS, Y. \& LESCOAT, P. (2010) Sequential feeding using 455 whole wheat and a separate protein-mineral concentrate improved efficiency in laying hens. $456 \quad$ Poultry Science, 80: 785-796. 
457 VAN KRIMPEN, M.M., KWAKKEL, R.P., REUVEKAMP, B.F.J., VAN DER PEET458 SCHWERING, C.M.C., DEN HARTOG, L.A. \& Verstegen, M.W.A. (2005) Impact of 459 feeding management on feather pecking in laying hens. Worlds' Poultry Science Journal, $460 \quad$ 61: 663-685. 
Table 1. Composition of experimental diets

\begin{tabular}{|c|c|c|c|c|c|c|}
\hline \multirow{3}{*}{ Ingredient $(\mathrm{g} / \mathrm{kg})$} & \multicolumn{2}{|c|}{ Habituation Period (16-18 week) } & \multicolumn{3}{|c|}{ Experimental Period (19-42 week) } & \multirow{3}{*}{$\begin{array}{c}\text { Both periods } \\
\text { Whole Wheat } \\
\text { (Triticum } \\
\text { aestivum) }\end{array}$} \\
\hline & \multirow{2}{*}{$\begin{array}{l}\text { Control habituation } \\
\qquad(\mathrm{CH})\end{array}$} & \multirow{2}{*}{$\begin{array}{c}\text { Balancer diet } \\
\text { habituation } \\
\text { (LH) }\end{array}$} & \multirow{2}{*}{$\begin{array}{l}\text { Control } \\
\text { (C) }\end{array}$} & Balancer diet & Balancer diet & \\
\hline & & & & B50 & $\mathrm{B} 25$ & \\
\hline Wheat & 346.6 & - & 500.0 & - & - & 100 \\
\hline Maize & 350.0 & 535.7 & 161.3 & 320.8 & 498.4 & \\
\hline Wheat bran & 100.0 & 153.1 & 25.4 & 50.1 & 45.0 & \\
\hline Maize gluten & - & - & 32.9 & 66.2 & 24.0 & \\
\hline Soya bean meal (T48) & 165.0 & 252.5 & 169.7 & 340.8 & 285.0 & \\
\hline Soya bean oil & - & - & 8.0 & 16.0 & 10.0 & \\
\hline Calcium carbonate & 18.4 & 28.2 & 80.0 & 160.4 & 105.1 & \\
\hline Bi-calcium phosphate & 10.9 & 16.7 & 11.6 & 23.3 & 17.4 & \\
\hline Refined sodium chloride & 2.0 & 3.1 & 2.0 & 4.0 & 2.7 & \\
\hline Sodium bicarbonate & 2.0 & 3.1 & 2.0 & 4.0 & 2.7 & \\
\hline L-Lysine 78 & - & - & 1.1 & 2.2 & 1.3 & \\
\hline DL-Methionine & 0.1 & 0.2 & 1.1 & 2.2 & 1.8 & \\
\hline Premix (Sup 64 J 02) ${ }^{1}$ & 5.0 & 7.7 & 5.0 & 10.0 & 6.7 & \\
\hline \multicolumn{7}{|c|}{$\begin{array}{l}\text { Calculated composition ( } \mathrm{g} / \mathrm{kg} \text { as fed } \\
\text { basis) }\end{array}$} \\
\hline Metabolisable energy (MJ/kg) & 11.7 & 11.0 & 11.5 & 10.0 & 11.0 & 13.0 \\
\hline $\mathrm{CP}$ & 160.5 & 183.3 & 175.2 & 233.2 & 194.7 & 119.0 \\
\hline $\mathrm{DM}$ & 877.0 & 875.0 & 891.0 & 899.0 & 889.0 & 868.0 \\
\hline Fibre & 35.9 & 41.0 & 30.1 & 33.7 & 32.7 & 26.5 \\
\hline Lysine & 7.2 & 9.3 & 8.1 & 13.1 & 10.7 & 3.1 \\
\hline Methionine & 3.2 & 3.9 & 4.5 & 7.1 & 5.7 & 2.0 \\
\hline Calcium & 12.0 & 18.2 & 36.1 & 72.0 & 48.0 & 0.3 \\
\hline Total P & 5.6 & 7.1 & 5.3 & 7.6 & 6.4 & 3.0 \\
\hline \multicolumn{7}{|l|}{ Analysed composition $(\mathrm{g} / \mathrm{kg}$ ) } \\
\hline $\mathrm{DM}$ & 890.0 & 887.0 & 888.0 & 895.0 & 890.0 & 867.0 \\
\hline $\mathrm{CP}$ & 157.0 & 186.0 & 173.0 & 230.0 & 195.0 & 119.0 \\
\hline
\end{tabular}

${ }^{1}$ Vitamin and mineral premix supplied the following amounts per kg of premix: $1200 \mathrm{mg}$ of Cu (sulphate), $4000 \mathrm{mg}$ of Fe, $200 \mathrm{mg}$ of I, $60 \mathrm{mg}$ of Se, $120 \mathrm{~g}$ of DL-methionine, 200

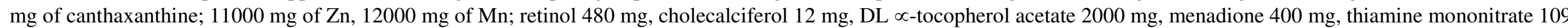
mg. 
Table 2. Effect of treatment, feeding system and balancer-diet composition on the feed intake and performance of hens fed whole wheat sequentially $(S)$ or in loose-mix $(L)$ with a balancer diet formulated for either 50 or $25 \%$ wheat intake from 19 to 42 weeks of age

\begin{tabular}{|c|c|c|c|c|c|c|c|c|c|c|c|c|}
\hline & $\begin{array}{c}\text { Feed } \\
\text { Intake } \\
(\mathrm{g} / \mathrm{b} / \mathrm{d})\end{array}$ & $\begin{array}{c}\text { Wheat } \\
\text { intake/Feed } \\
\text { intake }\end{array}$ & $\begin{array}{l}\text { Eggs } \\
\text { produced } \\
\text { per hen } \\
\text { per d }\end{array}$ & $\begin{array}{c}\text { Egg } \\
\text { weight }(g)\end{array}$ & $\begin{array}{l}\text { Egg } \\
\text { mass } \\
(\mathrm{g} / \mathrm{d})\end{array}$ & $\begin{array}{c}\text { FCE } \\
\text { (g egg/g } \\
\text { feed) }\end{array}$ & $\begin{array}{c}\text { BW wk } 19 \\
(\mathrm{~g})\end{array}$ & $\begin{array}{l}\text { BW wk } \\
42(g)^{2}\end{array}$ & $\begin{array}{l}\text { BWG } \\
(\mathrm{g} / \mathrm{d})\end{array}$ & $\begin{array}{l}\text { Egg } \\
\text { Yolk } \\
\text { (g) }\end{array}$ & $\begin{array}{c}\text { Egg } \\
\text { Albumen } \\
(\mathrm{g})\end{array}$ & $\begin{array}{c}\text { Eggshell } \\
(\mathrm{g})\end{array}$ \\
\hline \multicolumn{13}{|c|}{ Treatments } \\
\hline C & $114.4 \mathrm{ab}$ & - & $0.946 \mathrm{ab}$ & $57.3 \mathrm{ab}$ & $54.2 \mathrm{a}$ & 0.473 & $1560 \mathrm{a}$ & $1832 \mathrm{a}$ & $1.7 \mathrm{a}$ & $14.2 \mathrm{a}$ & 36.9 & $6.0 \mathrm{ab}$ \\
\hline S50 & $115.7 \mathrm{a}$ & $0.384 \mathrm{c}$ & $0.950 \mathrm{a}$ & $58.2 \mathrm{a}$ & $55.5 \mathrm{a}$ & 0.481 & 1588 a & $1810 \mathrm{a}$ & $1.4 \mathrm{ab}$ & $14.0 \mathrm{a}$ & 38.0 & $6.1 \mathrm{a}$ \\
\hline S25 & $111.5 \mathrm{ab}$ & $0.315 \mathrm{~d}$ & $0.947 \mathrm{a}$ & $58.4 \mathrm{a}$ & $55.3 \mathrm{a}$ & 0.498 & $1603 \mathrm{a}$ & $1809 \mathrm{a}$ & $1.1 \mathrm{ab}$ & $14.1 \mathrm{a}$ & 38.0 & $6.3 \mathrm{a}$ \\
\hline L50 & $107.0 \mathrm{bc}$ & $0.563 \mathrm{a}$ & $0.924 \mathrm{ab}$ & $57.2 \mathrm{ab}$ & $53.4 \mathrm{a}$ & 0.486 & $1485 \mathrm{~b}$ & $1722 \mathrm{ab}$ & $1.4 \mathrm{ab}$ & $14.0 \mathrm{a}$ & 37.2 & $6.1 \mathrm{a}$ \\
\hline L25 & $102.8 \mathrm{c}$ & $0.502 \mathrm{~b}$ & $0.886 \mathrm{~b}$ & $55.0 \mathrm{~b}$ & $49.0 \mathrm{~b}$ & 0.476 & $1545 \mathrm{ab}$ & $1622 b$ & $0.6 \mathrm{~b}$ & $13.2 \mathrm{~b}$ & 35.4 & $5.7 \mathrm{~b}$ \\
\hline$P$ value & $<0.01$ & $<0.01$ & $<0.05$ & $<0.05$ & $<0.01$ & NS & $<0.01$ & $<0.05$ & $<0.05$ & $<0.05$ & NS & $<0.05$ \\
\hline SEM & 0.97 & 1.20 & 0.69 & 0.35 & 0.50 & 0.004 & 8.10 & 17.73 & 0.09 & 0.09 & 0.30 & 0.04 \\
\hline \multicolumn{13}{|c|}{ Feeding system $^{2}$} \\
\hline $\mathrm{L}$ & $104.8 \mathrm{~b}$ & $0.532 \mathrm{a}$ & $0.904 \mathrm{~b}$ & $56.0 \mathrm{~b}$ & - & 0.480 & $1515 \mathrm{~b}$ & $1688 \mathrm{~b}$ & 1.1 & - & $36.4 \mathrm{~b}$ & - \\
\hline $\mathrm{S}$ & $113.7 \mathrm{a}$ & $0.350 \mathrm{~b}$ & $0.948 \mathrm{a}$ & $58.3 \mathrm{a}$ & - & 0.490 & $1596 \mathrm{a}$ & $1810 \mathrm{a}$ & 1.3 & - & $38.0 \mathrm{a}$ & - \\
\hline$P$ value & $<0.01$ & $<0.01$ & $<0.05$ & $<0.05$ & - & NS & $>0.01$ & $<0.05$ & NS & - & $<0.05$ & - \\
\hline SEM & 1.11 & 1.20 & 0.83 & 0.40 & & 0.005 & 9.52 & 20.23 & 0.09 & & 0.34 & \\
\hline \multicolumn{13}{|c|}{ Balancer Diet effect } \\
\hline 50 & $111.3 \mathrm{a}$ & $0.474 \mathrm{a}$ & 0.937 & 57.8 & - & 0.483 & $1535 \mathrm{~b}$ & 1766 & $1.4 \mathrm{a}$ & - & 37.7 & - \\
\hline 25 & $107.0 \mathrm{~b}$ & $0.412 \mathrm{~b}$ & 0.916 & 56.6 & - & 0.487 & $1573 \mathrm{a}$ & 1716 & $0.9 \mathrm{~b}$ & - & 36.9 & - \\
\hline$P$ value & $<0.05$ & $<0.05$ & NS & NS & - & NS & $<0.05$ & NS & $<0.05$ & - & $\mathrm{NS}$ & - \\
\hline SEM & 1.11 & 1.20 & 0.83 & 0.40 & & 0.005 & 9.52 & 20.23 & 0.09 & & 0.34 & \\
\hline \multicolumn{13}{|l|}{ Interaction } \\
\hline $\mathrm{FS} \times \mathrm{DC}$ & NS & NS & NS & NS & $<0.05$ & NS & NS & NS & NS & $<0.05$ & NS & $<0.05$ \\
\hline
\end{tabular}

${ }^{1} \mathrm{C}=$ Control, S50 = Sequential feeding of diet formulated for $50 \%$ wheat, S25 = Sequential feeding of diet formulated for $25 \%$ wheat, L50 = Loosemix feeding of diet formulated for $50 \%$ wheat, L25 = Loose-mix feeding of diet formulated for $25 \%$ wheat.

${ }^{2}$ Results were not presented where interaction between feeding system and balancer diet effect were observed

${ }^{\mathrm{a}, \mathrm{b}, \mathrm{c}}$ Values within the same column not sharing a common superscript differ significantly at $P<0.05$, NS $=$ not significant at $P>0.05$. 
Table 3. Effect of treatment, feeding system and balancer-diet composition on the feed, ME and protein intakes and ME and protein requirements of hens fed whole wheat sequentially $(S)$ or in loose-mix $(L)$ with a balancer diet formulated for either 50 or $25 \%$ intake of wheat from 19 to 37 weeks of age

\begin{tabular}{|c|c|c|c|c|c|c|c|c|}
\hline & $\begin{array}{l}\text { Feed intake } \\
(\mathrm{g} / \mathrm{b} / \mathrm{d})\end{array}$ & $\begin{array}{c}\text { Wheat } \\
\text { intake/Feed } \\
\text { intake }\end{array}$ & $\begin{array}{l}\text { ME intake } \\
(\mathrm{kJ} / \mathrm{b} / \mathrm{d})^{2}\end{array}$ & $\begin{array}{l}\text { ME Requirement } \\
(\mathrm{kJ} / \mathrm{b} / \mathrm{d})^{3}\end{array}$ & $\begin{array}{c}\text { Difference } \\
\mathrm{ME} \\
(\mathrm{kJ} / \mathrm{b} / \mathrm{d})^{4}\end{array}$ & $\begin{array}{l}\text { Protein } \\
\text { intake } \\
(\mathrm{g} / \mathrm{b} / \mathrm{d})\end{array}$ & $\begin{array}{c}\text { Protein } \\
\text { Requirement } \\
(\mathrm{g} / \mathrm{b} / \mathrm{d})\end{array}$ & $\begin{array}{c}\text { Difference } \\
\text { Protein } \\
(\mathrm{g} / \mathrm{b} / \mathrm{d}) \\
\end{array}$ \\
\hline \multicolumn{9}{|c|}{ Treatments $^{5}$} \\
\hline $\mathrm{C}$ & $113.1 \mathrm{a}$ & - & 1300.0 & $1321.4 \mathrm{a}$ & $-21.1 b$ & $19.8 \mathrm{~b}$ & $19.9 \mathrm{a}$ & $-0.1 \mathrm{ab}$ \\
\hline S50 & $113.6 \mathrm{a}$ & $0.387 \mathrm{c}$ & 1264.2 & $1311.0 \mathrm{a}$ & $-47.0 \mathrm{~b}$ & $21.4 \mathrm{a}$ & $20.1 \mathrm{a}$ & $1.3 \mathrm{a}$ \\
\hline S25 & $109.9 \mathrm{a}$ & $0.320 \mathrm{~d}$ & 1280.0 & $1308.1 \mathrm{a}$ & $-28.2 b$ & $18.7 \mathrm{bc}$ & $20.0 \mathrm{a}$ & $-1.3 b$ \\
\hline L50 & $106.6 \mathrm{ab}$ & $0.569 \mathrm{a}$ & 1274.0 & $1241.0 \mathrm{ab}$ & $33.0 \mathrm{ab}$ & $18.4 \mathrm{c}$ & $18.5 \mathrm{ab}$ & $-0.1 a b$ \\
\hline L25 & $101.5 \mathrm{~b}$ & $0.503 \mathrm{~b}$ & 1226.0 & $1178.1 \mathrm{~b}$ & $47.7 \mathrm{a}$ & $15.9 \mathrm{~d}$ & $17.4 \mathrm{~b}$ & $-1.5 b$ \\
\hline$P$ & $<0.01$ & $<0.01$ & $N S$ & $<0.01$ & $<0.05$ & $<0.01$ & $<0.01$ & $<0.01$ \\
\hline SEM & 1.00 & 1.17 & 9.20 & 10.30 & 9.00 & 0.23 & 0.23 & 0.22 \\
\hline \multicolumn{9}{|c|}{ Feeding system $^{6}$} \\
\hline $\mathrm{L}$ & $103.9 \mathrm{~b}$ & $0.533 \mathrm{a}$ & 1248.0 & $1207.0 \mathrm{~b}$ & $41.0 \mathrm{a}$ & $17.1 \mathrm{~b}$ & $18.0 \mathrm{~b}$ & - \\
\hline $\mathrm{S}$ & $111.8 \mathrm{a}$ & $0.354 \mathrm{~b}$ & 1272.0 & $1310.0 \mathrm{a}$ & $-37.7 b$ & $20.1 \mathrm{a}$ & $20.0 \mathrm{a}$ & - \\
\hline$P$ & $<0.05$ & $<0.01$ & $N S$ & $<0.01$ & $<0.01$ & $<0.01$ & $<0.01$ & - \\
\hline SEM & 1.12 & 1.17 & 10.50 & 11.61 & 10.60 & 0.27 & 0.27 & \\
\hline \multicolumn{9}{|c|}{ Balancer Diet effect } \\
\hline 50 & $110.4 \mathrm{a}$ & $0.472 \mathrm{a}$ & 1269.0 & 1279.2 & -11.0 & $20.0 \mathrm{a}$ & 19.4 & - \\
\hline 25 & $105.5 \mathrm{~b}$ & $0.415 \mathrm{~b}$ & 1252.3 & 1242.0 & 11.0 & $17.3 \mathrm{~b}$ & 18.7 & - \\
\hline$P$ & $<0.05$ & $<0.05$ & $N S$ & $N S$ & $N S$ & $<0.01$ & $N S$ & - \\
\hline SEM & 1.12 & 1.17 & 10.50 & 11.61 & 10.60 & 0.27 & 0.27 & \\
\hline \multicolumn{9}{|l|}{ Interaction } \\
\hline FS x DC & NS & NS & NS & NS & NS & NS & NS & $<0.05$ \\
\hline
\end{tabular}

${ }^{1}$ Values shown are averages from week 19 to 37 because body weight at week 42 was only measured for the birds used in the measurement of digestive organs.

${ }^{2}$ Estimation of $\mathrm{ME}(\mathrm{KJ} / \mathrm{b} / \mathrm{d})$ and protein $(\mathrm{g} / \mathrm{b} / \mathrm{d})$ intakes were calculated as the product of feed intake and diet composition.

${ }^{3}$ Requirements in ME (kJ/b/d) and protein (g/b/d) were estimated according to Sakomura (2004) and Sakomura et al. (2002) respectively.

Difference between requirement and intake were estimated as intake minus requirement.

${ }^{5} \mathrm{C}=$ Control, S50 = Sequential feeding of diet formulated for 50\% wheat, S25 = Sequential feeding of diet formulated for $25 \%$ wheat, L50 = Loose-mix feeding of diet formulated for $50 \%$ wheat, $\mathrm{L} 25$ = Loose-mix feeding of diet formulated for $25 \%$ wheat.

${ }^{6}$ Result were not presented where interaction between feeding system and balancer diet effect were observed.

${ }_{\mathrm{a}, \mathrm{b}, \mathrm{c}}$ Values within the same column not sharing a common superscript differ significantly at $P<0.05$, NS $=$ not significant at $P>0.05$. 
Table 4. Effect of feeding system on weight of digestive organs ( $\mathrm{g} / \mathrm{kg}$ body weight) at weeks 19 and 42 of birds fed whole wheat sequentially or in loose-mix with a balancer diet

\begin{tabular}{|c|c|c|c|c|c|c|c|c|c|c|c|}
\hline \multirow{3}{*}{ Organ $(\mathrm{g} / \mathrm{kg})$} & \multicolumn{5}{|c|}{ Week 19} & \multicolumn{6}{|c|}{ Week $42^{1}$} \\
\hline & \multicolumn{3}{|c|}{ Feeding system $^{2}$} & \multirow{2}{*}{$\begin{array}{c}P \\
\text { value }\end{array}$} & \multirow[b]{2}{*}{ SEM } & \multicolumn{3}{|c|}{ Feeding system } & \multirow{2}{*}{$\begin{array}{c}P \\
\text { value }\end{array}$} & \multirow{2}{*}{$\begin{array}{l}\text { SEM } \\
(\mathrm{n}=16)\end{array}$} & \multirow{2}{*}{$\begin{array}{c}\text { SEM } \\
(\mathrm{n}=24)\end{array}$} \\
\hline & $\begin{array}{c}\mathrm{CH} \\
(\mathrm{n}=8)\end{array}$ & $\begin{array}{c}\mathrm{SH} \\
(\mathrm{n}=8)\end{array}$ & $\begin{array}{c}\mathrm{LH} \\
(\mathrm{n}=8)\end{array}$ & & & $\begin{array}{c}C \\
(n=16)\end{array}$ & $S(n=24)$ & $\mathrm{L}(\mathrm{n}=24)$ & & & \\
\hline Proventriculus & 3.1 & 3.1 & 2.8 & $N S$ & 0.08 & $3.3 \mathrm{~b}$ & $3.7 \mathrm{a}$ & $3.3 \mathrm{~b}$ & $<0.05$ & 0.11 & 0.08 \\
\hline Gizzard & 18.5 & 21.9 & 21.7 & $<0.05$ & 0.62 & $11.8 \mathrm{~b}$ & $13.8 \mathrm{a}$ & $14.7 \mathrm{a}$ & $<0.05$ & 0.48 & 0.37 \\
\hline Duodenum & $5.4 \mathrm{ab}$ & $6.4 \mathrm{a}$ & $5.1 \mathrm{~b}$ & $<0.05$ & 0.21 & $5.2 \mathrm{~b}$ & $5.9 \mathrm{a}$ & $5.5 \mathrm{ab}$ & $<0.05$ & 0.20 & 0.18 \\
\hline Jejunum & 8.5 & 10.1 & 8.5 & $<0.05$ & 0.30 & 9.4 & 9.5 & 9.7 & $N S$ & 0.26 & 0.24 \\
\hline Ileum & $6.3 \mathrm{~b}$ & $7.5 \mathrm{a}$ & $6.2 \mathrm{~b}$ & $<0.05$ & 0.22 & 7.6 & 7.2 & 7.4 & $N S$ & 0.25 & 0.19 \\
\hline Liver & 24.7 & 25.1 & 24.4 & $N S$ & 0.74 & $25.5 \mathrm{~b}$ & $26.8 \mathrm{ab}$ & $28.9 \mathrm{a}$ & $<0.05$ & 0.76 & 0.91 \\
\hline Pancreas & 2.1 & 2.2 & 2.2 & $N S$ & 0.06 & $1.6 \mathrm{~b}$ & $1.8 \mathrm{a}$ & $1.8 \mathrm{a}$ & $<0.05$ & 0.06 & 0.06 \\
\hline
\end{tabular}

${ }^{1}$ No difference in organs weight between treatments of the same feeding system and no interaction (feeding system x balancer diet level) was observed. Therefore, animals receiving diet 25 were put together with their corresponding 50 treatments to increase the population size from 16 to 24 .

${ }^{2} \mathrm{CH}=$ Control Habituation, $\mathrm{SH}=$ sequential habituation, $\mathrm{LH}=$ loose-mix habituation, $\mathrm{C}=\mathrm{Control}$, L = Loose-mix, $\mathrm{S}=\mathrm{Sequential}$ a,b,c: Values within the same row not sharing a common superscript differ significantly with Bonferroni-Dunnet $(P<0.05)$, NS $=$ not significant at $P$ $>0.05$. 
a. Body weight (g)

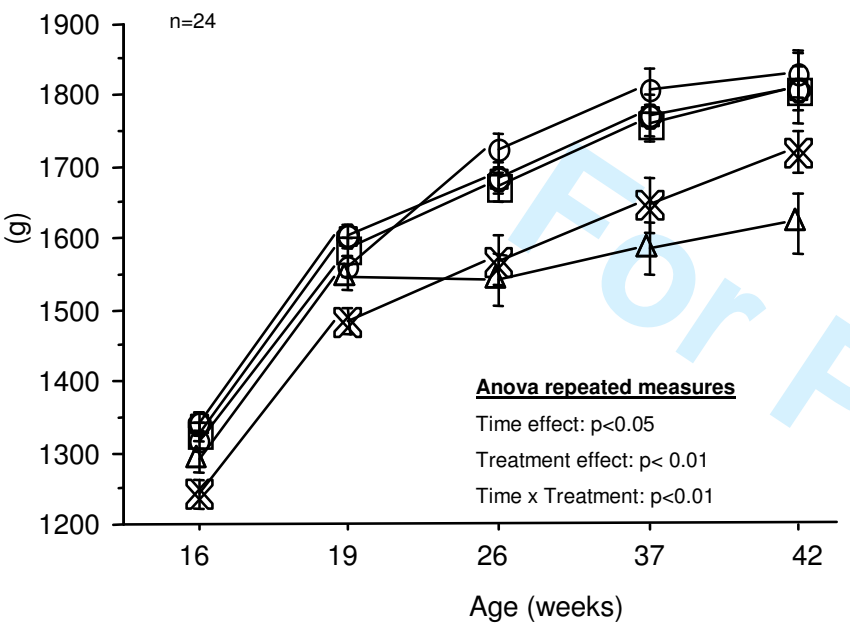

c. Wheat intake (\% total feed intake)

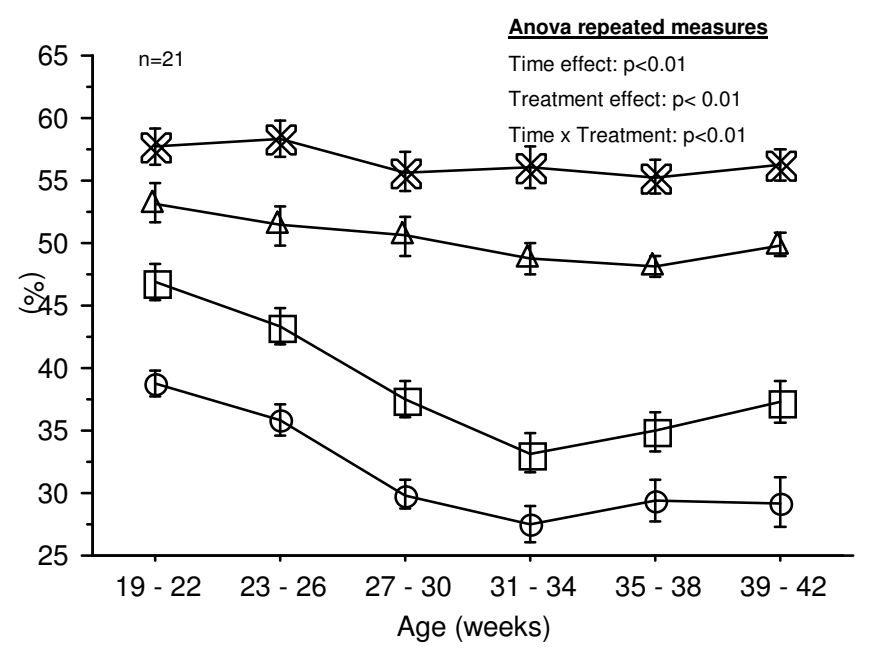

b. Feed intake (g/bird/d)

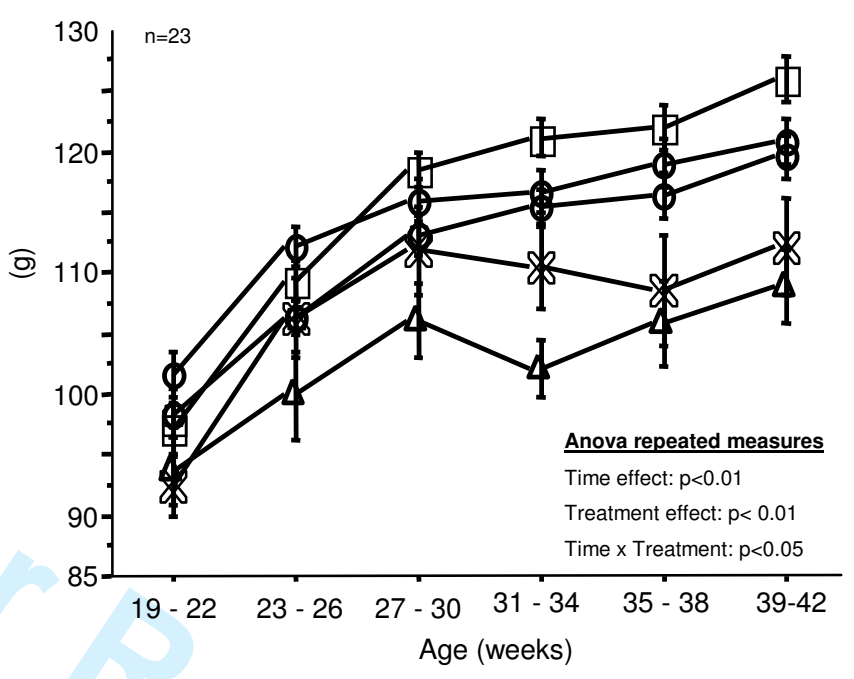

d. Egg mass (g/d)

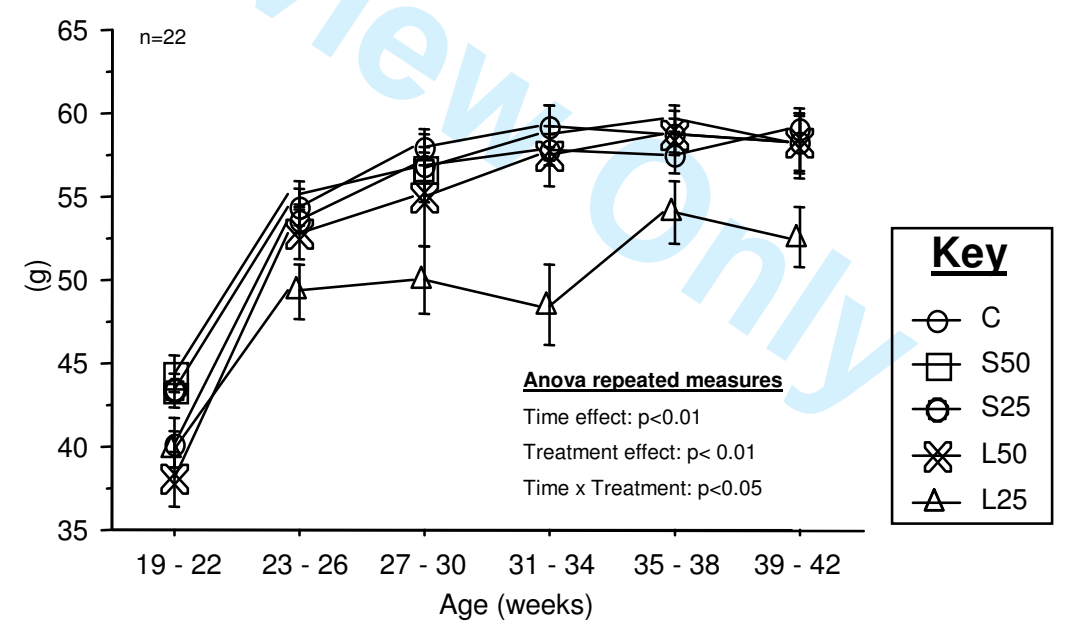




\section{Page 25 of 25}

1

592

3593 4

5

6
7

8

9

10

11

12

13

14

15

16

17

18

19

20

21

22

23

24

25

26

27

28

29

30

31

32

33

34

35

36

37

38

35

40

41

42

43

44

45
Figure. Individual variation within treatment in $(a) B W,(b)$ Feed intake, (c) wheat intake and (d) egg mass of birds fed whole wheat sequentially (S) or in loose-mix $(L)$ with a balancer diet formulated for either 50 or $25 \%$ intake of wheat from 19 to 42 weeks of age. 